\title{
DRAWING FOR HERITAGE DISSEMINATION. THE BIRTH OF MADRID'S CIUDAD UNIVERSITARIA
}

\author{
JOSÉ LUIS GONZÁLEZ CASAS \& JARA MUÑOZ HERNÁNDEZ \\ Department of Architectural Graphic Ideation, Universidad Politécnica de Madrid, Spain.
}

\begin{abstract}
Madrid's Ciudad Universitaria is one of the busiest and at the same time the most unknown complex of buildings in the Spanish capital. In 2017, this declared Asset of Cultural Interest (BIC) turns 90 years of history, since the Building Board Committee which developed the project was created in 1927. Its construction, which was started in the 1930s, was strongly affected by the Civil War, which left on it several scars, some of which are still visible today. The purpose of this study is to analyse the factors that made that Ciudad Universitaria's project didn't start from a blank page. In 1927, La Florida former royal estate was occupied by various institutions, one among them being academic: the School of Agricultural Engineers, which had settled there in 1869, when most of the land was leased to it. During the construction of the Ciudad Universitaria, its extension was reduced; however, the main building was respected. Although deeply altered, it is today located in the heart of the campus. The 'medical group' was the other conditioning element of the project, since one of the main reasons for the Ciudad Universitaria's construction was providing Madrid with better health facilities. Along with the Clínico Hospital, the faculties of Medicine, Odontology and Chemistry were an essential part of the operation. Our research focuses on the two aforementioned main elements: the School of Agricultural Engineers as a heritage and the Medicine complex as a motivation, to understand the birth of the Ciudad Universitaria. These results of this piece of work are developed through new available drawing tools (the combination of two- and three-dimension image animations and geographical information systems), together with more traditional methods. This case is useful to explore graphic methods as extraordinary powerful tools to analyse, study and spread our heritage.

Keywords: 20th century, dissemination, drawing, heritage, landscape, Madrid, model, university.
\end{abstract}

\section{INTRODUCTION}

During the first few decades of the Spanish 20th century, Madrid's Ciudad Universitaria was probably the biggest economic, cultural and social investment, one which indeed arose many expectations and hopes too. Located on the grounds of the ancient La Florida estate, in the Northwest of the city, its design was developed looking towards foreign Modernity, to import some of its university concepts and to combine them with the Spanish model: 'the English scheme of colleges + sports, the German combination of seminars and laboratories, the Spanish traditional administrative unit, and the American campus, with its selective and elitist burden, but without its basic determinants and its philanthropy and profitability' [1]. In order to explain this creative process, we have used the graphic reconstitution, which enables us to systematize data from mapping, written and photographic sources from the late 19th century and early 20 th century.

\section{THE HERITAGE: LA FLORIDA ROYAL ESTATE}

La Florida and La Moncloa Royal Estate was born during the reign of Charles IV out of the merge of some royal properties and other nearby areas [2]. It was the last Royal Estate to be founded in Madrid and its interest lay, besides its lush gardens and orchards by the river bank, in its closeness to the city and its location between the Royal Palace and El Pardo Royal Estate, allowing the king to go hunting in the mount without leaving his domains. 
In 1928, the State gave the land to the Public Education Ministry. These grounds, and some other properties acquired through purchases, transfers or swaps, together resulted in a 320 ha plot of land where the Ciudad Universitaria would be established.

The boundaries of La Florida estate were not uniformly precise: while they were well-defined towards the North, established by El Pardo walls, the Eastern border was more irregular, crossing water courses and bordering on grounds of varied owners. To the South, it merely bordered the local Parque del Oeste, and the Western border was La Coruña road, which ran parallel to the Manzanares River (Fig. 1). This resulting enclosed area had a hilly and uneven topography, which can be considered as a high plateau above the river, crossed from east to west by several parallel water courses, being prominent among them the Cantarranas stream, because of its length and depth.

\subsection{The School of Agricultural Engineers}

On the plot where Madrid's Ciudad Universitaria would be settled, the oldest academic institution was the School of Agriculture. Although it was a faculty, its origin is previous to the project of the campus. It was founded in Aranjuez in 1855 and established in La Flamenca estate. Because of its functional demands, this was one of the first academic buildings located out of the urban city centre, since the requirements for practice fields called for great extensions of rural land in the surroundings. Two sections were established according to a series of educational

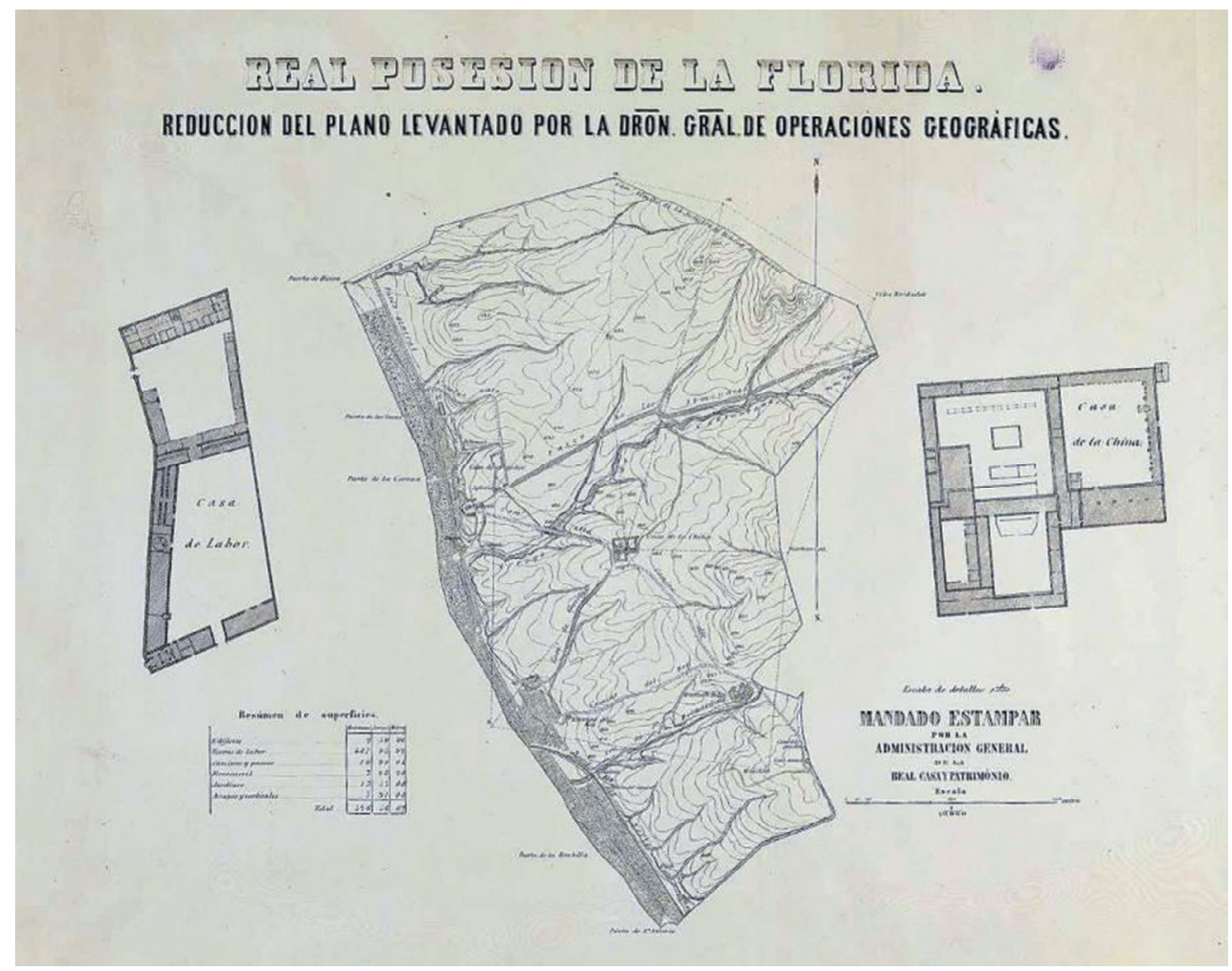

Figure 1: Plan of La Florida Royal Estate. 1865 (Instituto Geográfico Nacional). 
criteria: a scientific and a technological one. They were so successful that some years later, the same educational model was introduced in the Agronomical Institute of Versailles.

After La Gloriosa Revolution, in 1868, the School of Agriculture was moved to the estate called La Florida or La Moncloa in Madrid, one of the disentailments of the Crown's properties. In La Florida, the School was established in the former Royal Porcelain Manufactory, also known as Casa de la China. This building was destined for teaching purposes, but the need for more space resulted in an expansion of the institution over La Florida, occupying buildings close to La Moncloa Palace with farms, dormitories and kitchens. The School also controlled the grounds and buildings nearby (Fig. 2). From 1876, it was called Superior Technical School of Agricultural Engineers, and in 1880, the works finished and the education could be completely developed in the 500 ha available, according to the topographical survey carried out from 1861 to 1864 [3].

Over time, the terrible conditions which the Porcelain Manufactory was in led to demands for a new building, which, deeply altered, has survived to the present day. Designed by the architect Carlos Gato Soldevilla, it opened in 1924 and stylistically was an eclectic construction with a 19th-century appearance. Aiming to recall the architecture of the close by La Moncloa Palace, it showed the typical contrast between different coloured bricks of the walls and the stone in the orders of columns, cornices and friezes.

From 1927, when the campus was first located on these grounds, the available surface for practice fields decreased gradually to include all the faculties, until the point that the extension soon became inadequate to fulfil its original mission.

\subsection{Buildings and landscape in La Florida}

The new buildings of Ciudad Universitaria, whose construction lasted the 1920s, were opened from 1933, and had to remain together with others that already existed in La Florida.

Very close to the School of Agriculture, the Casa de Velázquez was set. The School of High Hispanic Studies was opened in Madrid in 1909, promoted by the University of Bordeaux, to receive French researchers during their formative stage. Shortly after, Alfonso XIII gave France in usufruct a plot of land in La Florida. The works started in 1920 and finished by 1935. It was a building of eclectic style that reminds us of the works of Juan Gómez de Mora - architect, among other works, of the Plaza Mayor in Madrid - which was completed with the main front of the Oñate Palace, a gift from Madrid's City Council. Both buildings, the Casa de Velázquez and the School of Agriculture, were victims of the war that we can still see [4]. However, there were buildings in the initial Ciudad Universitaria that nowadays only

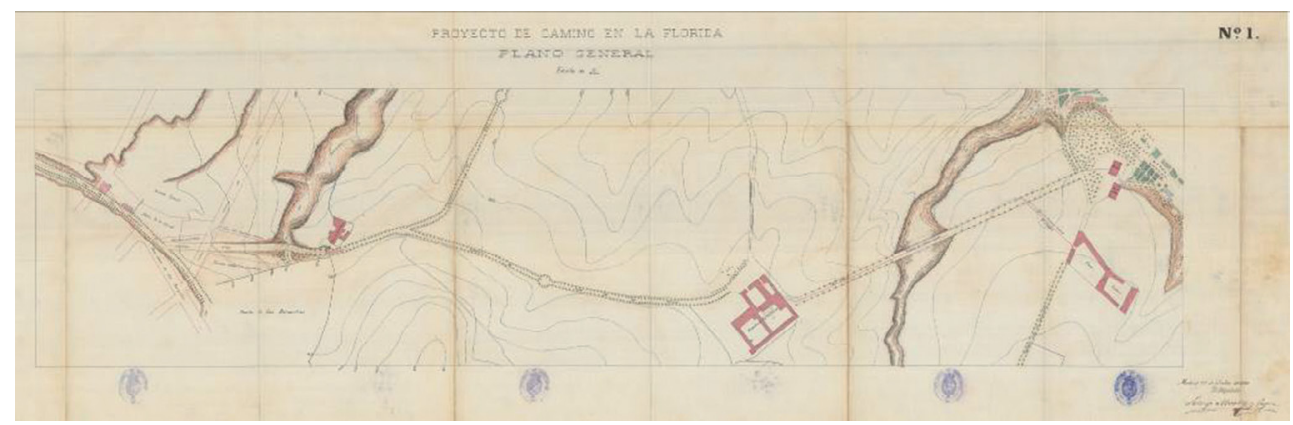

Figure 2: Project of a road in La Florida. 1880 (Archivo General de la Administración). 


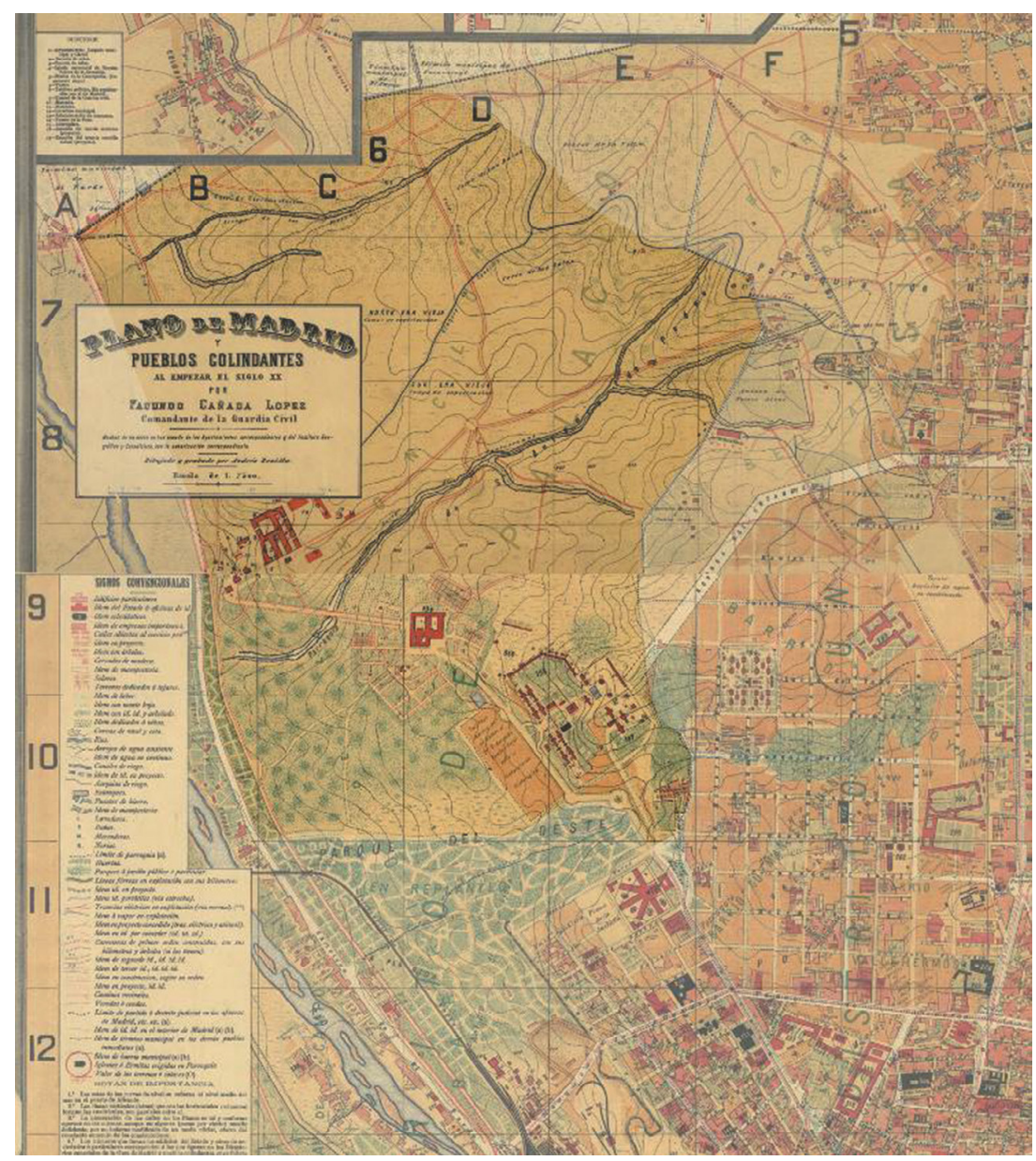

Figure 3: Plan of Madrid at the beginning of the 20th century by Facundo Cañada (detail).

exist in old photographs or pictures. This is the case of the Institute of Hygiene, the Rubio Institute, the Santa Cristina Asylum or the National Shooting Field, all disappeared, and La Moncloa Palace, very different from the building we know today.

The arrangement of these buildings on the grounds is shown on the detail of the plan of Madrid drawn in 1905 by Facundo Cañada (Fig. 3), where La Florida has been highlighted.

In terms of landscape, this was a very diverse territory. To the North, there was an old and leafy pine forest, which closed the views from the plateau in that direction. Throughout the drier centre, crops, vineyards and olive groves were grown, taken care of by the School of Agriculture. The plain of the Manzanares River, to the West, was an elongated strip of land particularly luxuriant, due to the humidity of the river and the water courses that flowed into it. There, a series of ancient gardens grew, which is remains of the former La Florida Royal Estate, which were very popular among the locals. This success motivated misgivings and critics towards the location here at the Ciudad Universitaria, as it was understood as a loss of one of the most beloved parks in the city. Many other gardens had been already distorted after the arrival of the School of Agriculture [5]; however, ever since, the type of orchard-garden had been fostered. It was a very interesting alternative where crops, forests and spontaneously 


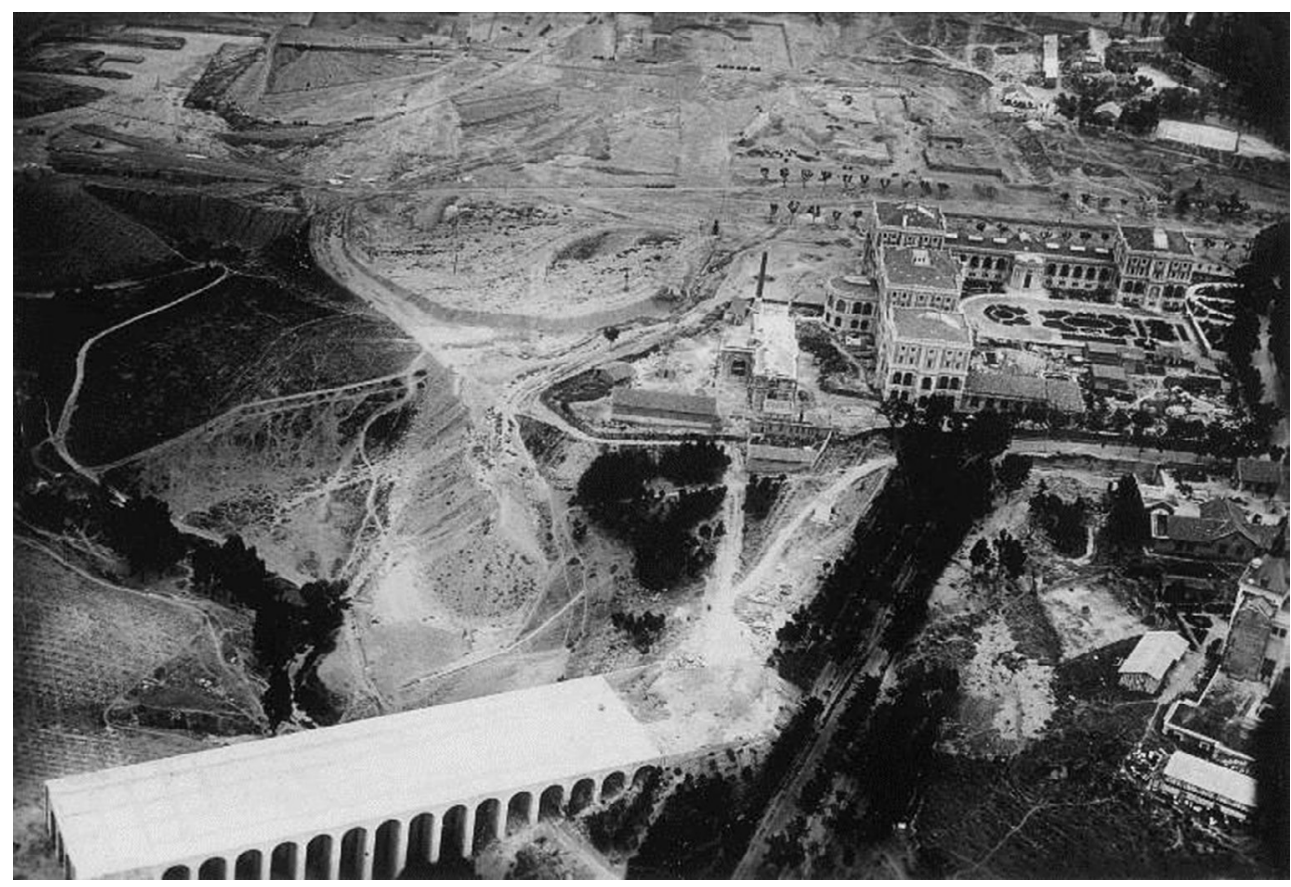

Figure 4: 'Quince Ojos’ Viaduct and School of Agriculture (Biblioteca Histórica UCM).

grown shrubs coexisted. The King's Walk connected all these gardens, from the Institute of Hygiene to the walls of El Pardo, parallel to La Coruña road.

Besides the buildings and the garden areas, this place was covered by transport infrastructures, as González Cárceles reports [6]. From 1902, a steam tramway travelled through the estate; in 1880, an animal traction tram ran from La Moncloa Square to the School of Agriculture; and in 1916, two more tram lines travelled through La Florida.

This was the general appearance of La Florida in the early 20th century and the one which the architects of Ciudad Universitaria would have to work with, deciding whether to respect the existing elements or to forget them in order to develop the new layout (Fig. 4).

\section{THE PROJECT OF CIUDAD UNIVERSITARIA}

The idea of a new university for Madrid was born in 1917, becoming more sophisticated over the following years. Starting from a medical complex, the project grew up to become a complete campus, which would be able to gather all the different areas of knowledge.

The most interesting points of the debate focused on the future location of the campus. The closest people to the King supported the idea of La Florida, a point of view that did not take into consideration a series of facts, such as the small area which was available, only 35 ha, and the consequent need for future purchases of land. The loss of one of Madrid's most popular public parks was also ignored. Among the advantages, the supporters of this plan pointed out the proximity to Madrid and the existence of some charitable institutions which would become complete with the addition of the hospital and the Faculty of Medicine.

The first sketches of Ciudad Universitaria can be found in Javier de Luque's project, which suggested a sanitary complex of buildings, consisting of a hospital, health research buildings, 


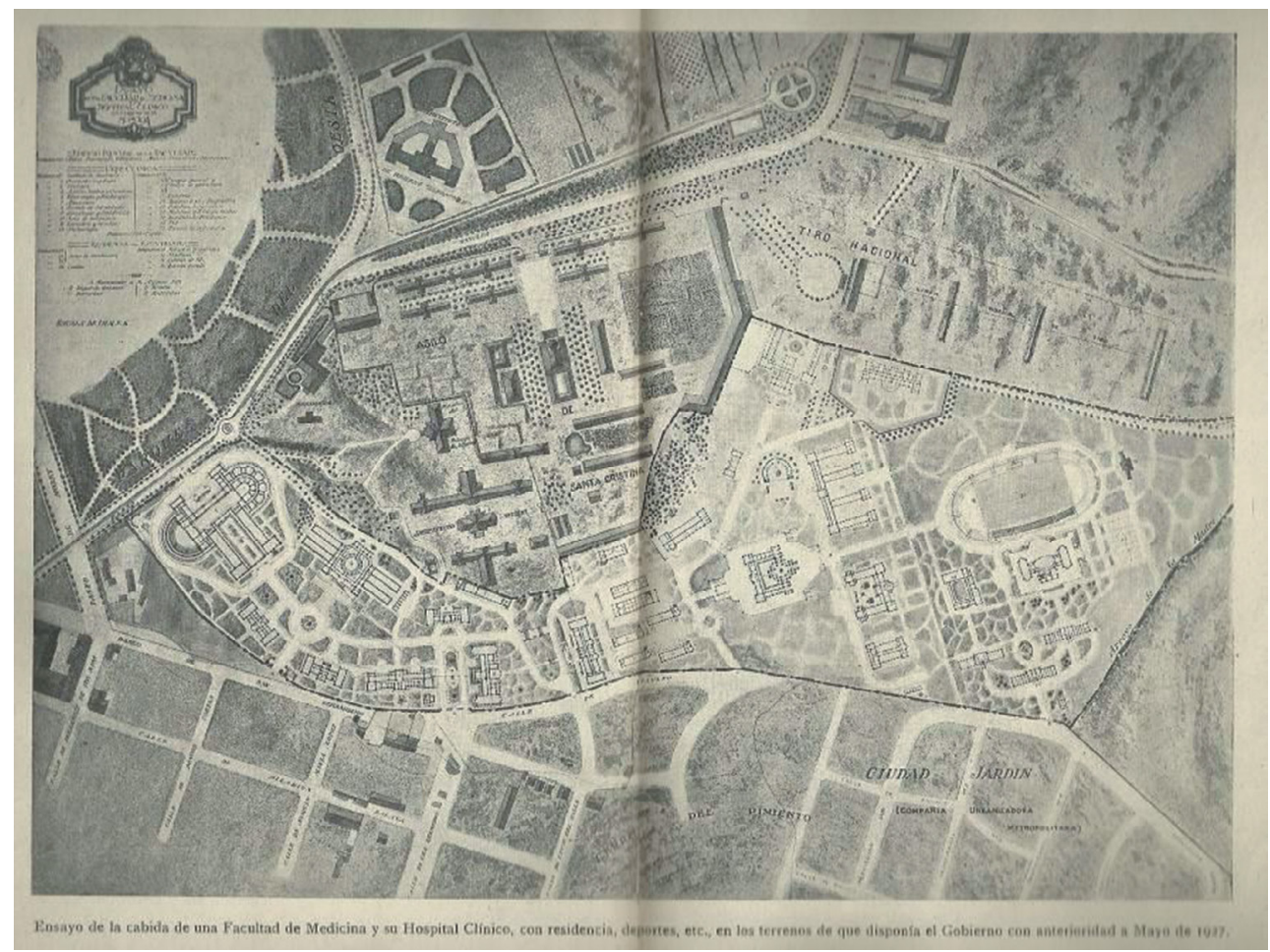

Figure 5: Project of a Medicine Faculty and a hospital, 1918 (Javier de Luque).

accommodation for students and sports fields [7]. It was set at the east of the Asylum and the Shooting Field (Fig. 5). Eventually this project was discarded, aiming for more ambitious ones.

The building works began and the project took place on empty lots and bare hills, but also over labour lands, crops and farms exploited by the School of Agriculture, and over gardens and meadows used as public parks. The uneven topography of La Moncloa was greatly modified to get a flat ground to place future buildings. Expensive excavation works were carried out, as shown in photographs and short films of the time (Fig. 6).

Despite these changes, a few pre-existing buildings were preserved, as well as part of the road network. Sometimes, this was due to the impossibility of relocating them, while other times, the function of the building was important enough to be preserved. This was the case of the School of Agriculture, located in such a central area of the domain; it became a key element in the design of the urban structure of the project. The main axis of the Ciudad Universitaria started at the end of La Moncloa Walk, and ended in the Assembly Hall. Had the school not existed, it is logical to think that this monumental axis would have rather started in La Moncloa Square, in order to emphasise the relationship between Madrid and the Assembly Hall. However, the existence of the Agricultural building and the tramway, lead to breaking the axis and set its beginning from this point.

The medical campus played an important role in the project as well. The Faculty of Medicine of Madrid was created in 1845 and, together with the Faculties of Chemistry and Dentistry, was located in different obsolete buildings in old Madrid. The current faculties, arranged around the Ramón y Cajal Square were designed by architects belonging to the 


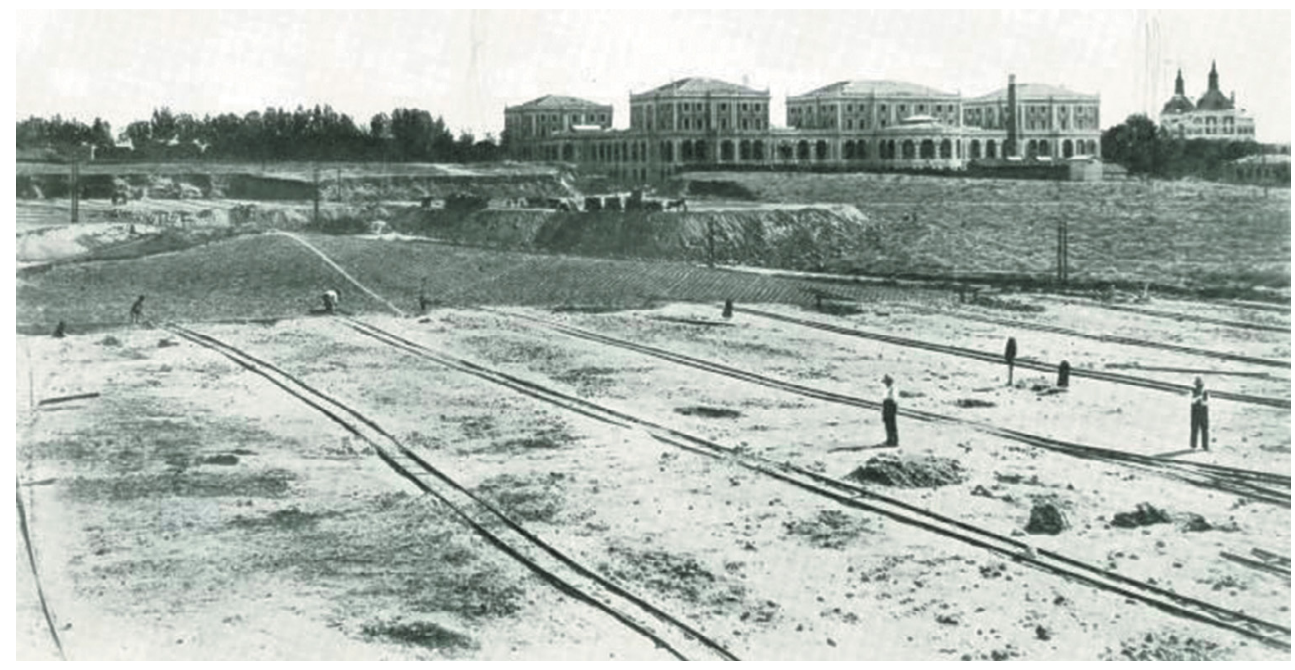

Figure 6: Excavation and cutting works, ca. 1930 (AGUCM).

so-called Generación del 25, who began to introduce the Modern Movement in Spain. These buildings were characterized by the use of brick masonry on their façades, the modulation and the simplicity of their lines. Because of their position, content and size, they became the most representative part of the campus. As the project advanced, a space for Fine Arts was also planned, located in the West part of the Ciudad Universitaria. The School of Agriculture lost most of its practice fields and became a hinge between the medical faculties and the artistic ones, just at the dividing point of the two main streets. The Sciences Complex was located on the right end of the main axis and the Letters Complex on the left end.

The Spanish Civil War started in July 1936 and arrived in November to the Ciudad Universitaria, which was transformed into a battle field until the end of the war in 1939. The School of Agricultural Engineers was placed first in line of combat, resulting half-destroyed. The Faculty of Dentistry also suffered numerous damages, while the Faculties of Medicine and Pharmacy only had slight impacts on their façades [8]. After the war, the new authorities continued the project of the campus, adapting it to the new image of the regime. Many buildings were repaired or reconstructed, such as the Faculties of Medicine, Pharmacy and Dentistry, and other ones were completely redesigned in a new style, as was the façade of the School of Agriculture, for example.

During the next few decades, the fields which belonged to La Florida were filled with new constructions. Nowadays, we must ask ourselves whether the first ideas of the campus have been respected or if the original project has been distorted and the old landscape deformed beyond recognition.

\section{GRAPHIC METHODOLOGY FOR THE DISSEMINATION OF THE PRESENT RESEARCH}

Drawing is our main means of transmitting the results and current state of our research. In this study case, we have worked with several well-known tools as well as experimented with new ones, or merging some of them, in order to show the important role of drawing and its great potential in the knowledge and dissemination of architecture [9]. 
In this piece of work, we try to bring together graphic edition and experimentation as a scientific process. Rigour is essential, first of all, to approach the past in a more precise way, and secondly because an accurate graphic production is extremely useful, in hindsight, when intervening on heritage. In addition, dissemination is a key instrument to make people who live in this space daily become aware of heritage around them and value the history behind it. We consider this as a primary first step in the protection of our heritage.

In this research on the early stages of Madrid's Ciudad Universitaria, we consider two scales: (i) a large scale to comprehend La Florida area and (ii) a closer one around the School of Agriculture and the Medicine Square. We use two- and three-dimension drawings in the approach at both scales.

Furthermore, four time sections have been set to compare the appearance of the Ciudad Universitaria at different points of time: 1926, the previous state; 1936, showing the campus before the war; 1956, after the reconstruction; and 2016 as a sample of the present state.

\subsection{The territory and the relationship with the city}

On the large scale, some digital terrain models (DTM) have been produced to understand how the topography of La Florida was like before being modified. Using this DTM, fairly reliable comparative studies of the terrain before and after the construction of the Ciudad Universitaria can be established. The current DMT is nowadays available to the public; the 1926 model is obtained from contour lines of old plans that are managed via geographic information systems. The plan drawn by the Geographical and Cadastral Institute in 1927 to call for the international competition for the campus master plan is very accurate, thereby resulting in a high level of precision when producing the model.

Coloured images of the DTM and contour lines can be used either as a base for planimetries or to create three-dimensional models. Besides conventional 3D models, apparent models are produced using bump maps obtained from DTM images, where the white areas represent the higher points and the darker areas represent the lower ones, with the advantage of it being a lighter file to work with. In this way, we have included greenery through an object replication plug-in for 3D software. Thus, tree-lined streets are created modelling only one tree, which is virtually repeated along a line; forests are formed by this same tree but repeated randomly with a chosen density; and orchards follow the scheme of forests but introducing an orthogonal pattern when scattering.

Finally, plans on this large scale have been produced for each of the time sections (1926, 1936, 1956 and 2016) merging both two and three dimensions. The process starts with a scientific georeferenced drawing, which is edited with textures or old plans as background and mixed with layers containing 3D elements, which allow us to add lights and shadows. The aim of these plans is to obtain drawings the same scale and with the same editing criteria to make a meaningful comparison between historic moments (Fig. 7).

The starting point is the current state of the Ciudad Universitaria of which there are digital plans available. From then, it is a back-in-time process, considering which buildings existed then and which did not, how the landscape was and which infrastructures the Ciudad Universitaria was provided with. This information is sometimes clearly dated and sometimes not so. In this last case, we must develop revisable hypothesis, in an exercise of graphic reconstitution rather close to a project design. 


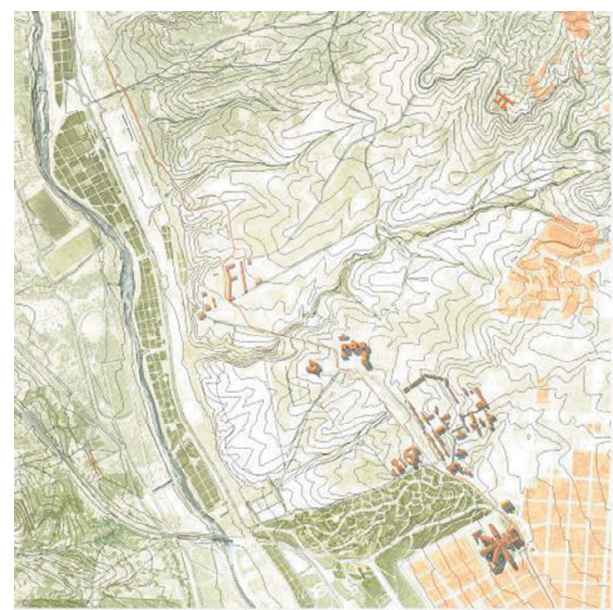

$\cdot 1926 \cdot$

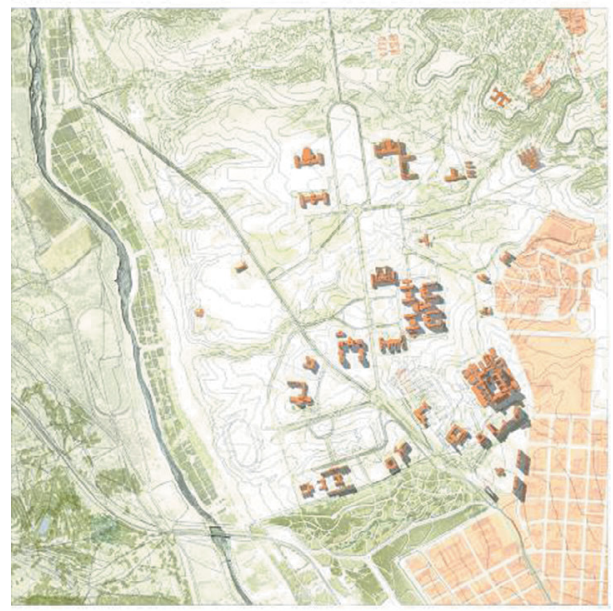

$\cdot 1956 \cdot$

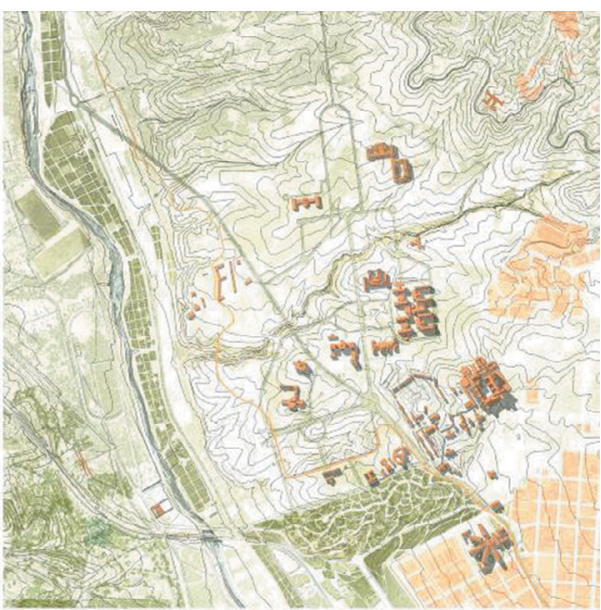

$\cdot 1936$.

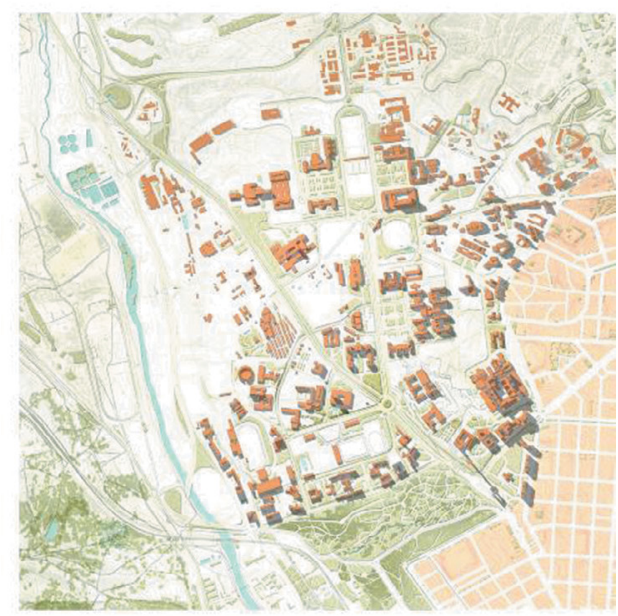

$\cdot 2016 \cdot$

Figure 7: State of the Ciudad Universitaria in 1926, 1936, 1956 and 2016 (J.L González, L. Mauleón y J. Muñoz. ETSAM).

\subsection{The architecture}

Data collection is essential when producing plans at a small scale. In order to draw the plans and sections of the Faculties of Medicine, Dentistry and Pharmacy, measurements of the current buildings have been made, starting with free-hand sketches and laser devices to take general measurements as a first approach. This step provides a better knowledge of the building from the start, in order to plan a more exhaustive data collection and the subsequent drawing. First sketches show the building's order, the modulation and the repeated elements. Once studied, a survey of the buildings is done with a total station and other measuring instruments. The drawing of small details of the buildings is made with traditional measuring methods 
supplemented with photogrammetry. The examination of these details is useful to spot small variations between apparently identical elements. The cause for these differences could possibly be problems arisen over the construction, material changes, decisions taken during the works, etc. In this case, these small changes are usually due to repairs taken place after the war, which are useful to identify the reconstructed areas and to reconstitute the condition of the building at the end of the Civil War.

The next step after drawing the plans of the current buildings is its comparison with the original plans of the project or those of posteriors refurbishments. Collecting all the plans of the different faculties, three-dimensional surveys have been developed, either modelling with a high level of detail or mapping the original plans on simple extrusions.

When modelling the School of Agricultural Engineers, one module has been built, containing the order of column, cornice, frieze and brick wall, and the complete building has been reconstructed from it afterwards. For the buildings of Medicine, Pharmacy and Dentistry, where the modulation is even clearer, a similar process has been followed.

The interest of these models goes beyond obtaining three-dimensional pictures of the nolonger-existing building: when studying old and current photographs and placing the same cameras inside the model, we are able to obtain very accurate comparative images, which enable us to reconstitute the initial Ciudad Universitaria.

Old photographs have been another useful source of information to contrast with plans and paintings, particularly valuable as they are much more objective than drawings. Besides, comparing photographs from different times enables an approach of heritage to the general public, placing it in the context of the moment. It results, therefore, as an extremely helpful tool for diffusion of culture.

We do not consider our work methods as separate elements, but as a combinable set of tools; thus, working with photographs is a two-way path in addition to the rest of graphic and written methods, as shown in Fig. 8. The first step when comparing photographs of a specific area or building is knowing what has been written about it and studying the existing plans to set the date and place where the picture was taken. Pictures ought to be checked and identified before we proceed to work with them, since wrongly described photographs are quite common. One of the consequences of the Civil War was, indeed, the destruction and general disorder of the documents stored in the faculties. After the fight, the widespread chaos caused many photographs to be catalogued quickly and incorrectly. The misfortune for the School of Agricultural Engineers was even greater, since the east wing of the building, where the library was located, was blown and completely destroyed, thus little graphic and written documents were able to be preserved.

Once the location of the photograph is identified, two- and three-dimensional drawing gains importance, because it is possible to place the photographer's position on the plans rather accurately and then, setting the cameras inside the 3D models, an even higher precision can be reached. This allows us to take a current picture from the same position the old one had, whenever it is still possible, and also to produce renders from the model in this same location (Fig. 9). Eventually, two pictures from the same place at different times can be compared and deeply analysed. A thorough study of these photographs helps to work out details that do not appear on plans and to adjust, in the models, the changes carried out during the construction, which were not updated on plans afterwards. In addition, photographs are a precious source to find out the original finishes of these buildings and learn how much they have changed. The skin of the buildings is one of the parts which changes the most over time, so these documents are a reliable source for their restitution. 

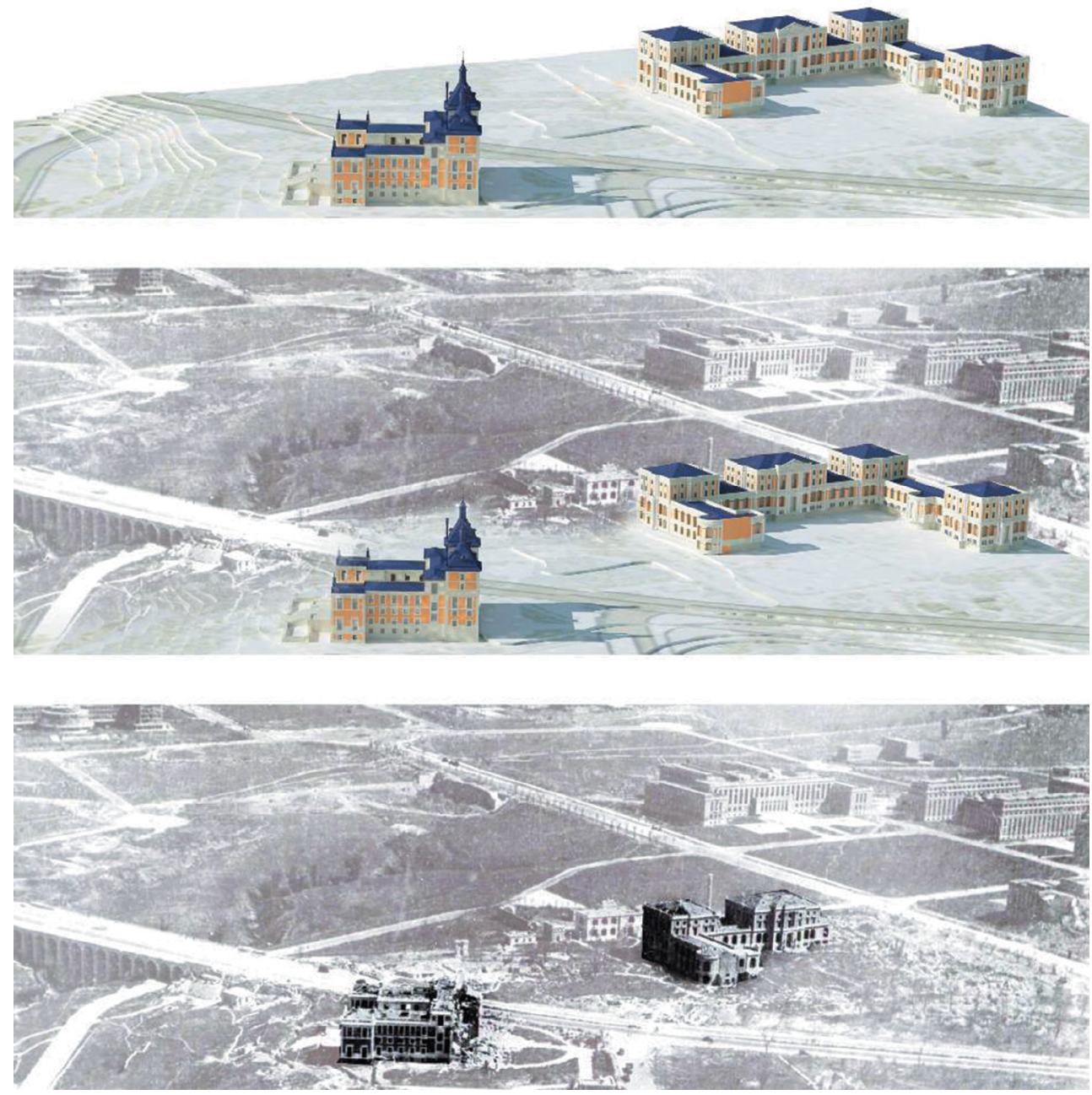

Figure 8: Casa de Velázquez and the School of Agriculture, before and after the war (J.L González, L. Mauleón y J. Muñoz. ETSAM).

\section{CONCLUSION}

The development of the cities and their modern infrastructures has changed deeply the way we see and live public spaces. This point is essential in the dissemination of heritage, since it is difficult to understand what the original projects were like before the construction of trams, underground lines, parking lots or even the disappearance of some of them. Nowadays, most users of the campus arrive through Ciudad Universitaria metro station. However, the underground did not reach the Ciudad Universitaria until January 1987, the arrivals, circulations and points of view being completely different. The university complex of buildings was designed to be accessed by tram, bus, car or on foot, creating lineal circulations from the city to the faculties. On the contrary, most people arrive today from a central point in the campus, where the metro station is. From here, radial circulations reach each one of the faculties. The way of approaching the place has also changed. Originally, a progressive movement from the city was done; nowadays, the access is faster from the underground to the centre of 


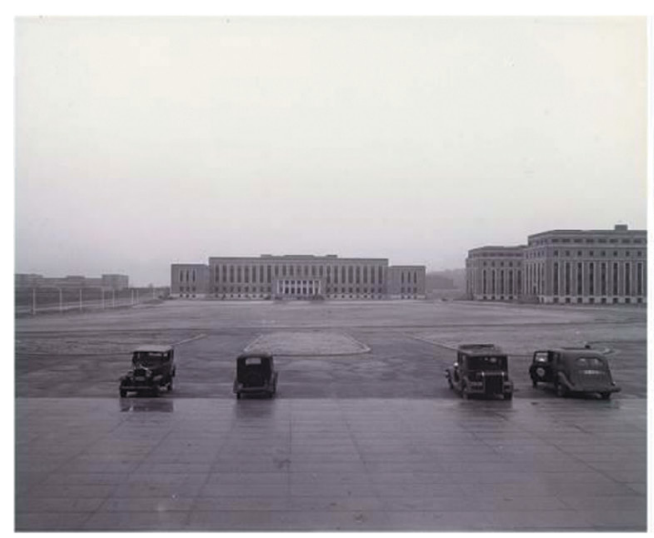

-FOTO Ca.1945

PLAZA DE RAMÓN Y CAJAL

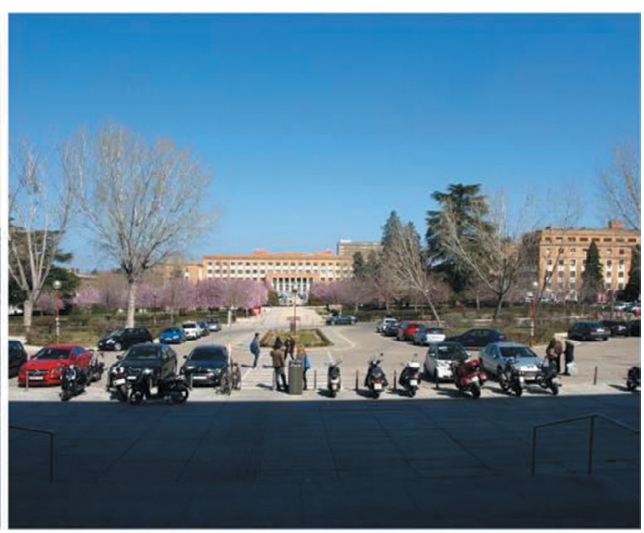

- FOTO DE 2015

PLAZA DE RAMÓN Y CAJAI

Figure 9: Ramón y Cajal Square in 1945 and 2015 (J.L. González).

the Ciudad Universitaria. This implies a new reflection on how to show the general public the way of seeing and living heritage. As Claude Parent and Paul Virilio intended with their theories of the oblique architecture, space can be understood not only in its conventional interpretation but in all its dimensions [10]. Besides the changes in spatial comprehension that new infrastructures have represented, they have a great potential as channels of information and platforms to show citizens heritage within the city and explain to them how these places were and how they currently are. To achieve this, it is essential to combine the use of the available graphic media as detailed above. This way, citizens will be more conscious of the environment they live in, increasing their sensitivity towards heritage and appreciating its protection and preservation.

\section{REFERENCES}

[1] Chías Navarro, P., Madrid's Ciudad Universitaria, Universidad Complutense de Madrid: Madrid, pp. 20-36, 1986 (in Spanish).

[2] Fernández Talaya, M.T., La Florida and La Moncloa Royal Estate: Historical and Artistic Development of a Madrid Site, Fundación Cajamadrid: Madrid, pp. 47-50, 1999 (in Spanish).

[3] Urteaga González, L. \& Camarero Bullón, C., The plans of the Spanish Royal Estates produced by the General Board of Statistics, 1861-1869. Scripta Nova. Electronic Journal of Geography and Social Science, 18(482), available at www.ub.es/geocrit/sn/ sn-482.htm, 2014 (in Spanish) (accessed 23 March 2016). ISSN:1138-9788.

[4] Rodríguez López, C., Landscapes of a War: Madrid's Ciudad Universitaria, Universidad Complutense de Madrid: Madrid, pp. 21-31, 2015 (in Spanish).

[5] Winthuysen, J., Spanish Classical Gardens: Castile, Imprenta Industrial Gráfica: Madrid, pp. 117-123, 1930 (in Spanish).

[6] González Cárceles, J.A., The recovery of the palace. An intense history. La Moncloa Palace, Its Past and Present (facsimile), ed. J. Ezquerra del Bayo, Presidencia del Gobierno: Madrid, pp. 3-25, 2009 (in Spanish).

[7] De Luque, J., Ciudad Universitaria of Madrid, Góngora: Madrid, pp. 15-54, 1931 (in Spanish). 
[8] Calvo González-Regueral, F., The Civil War in the Ciudad Universitaria, La Librería: Madrid, pp. 128-398, 2012 (in Spanish).

[9] Ortega Vidal, J., Martínez Díaz, Á. \& Muñoz de Pablo, M.J., Drawing and building life. EGA. Journal of Architectural Graphic Expression, 18, pp. 50-63, available at http:// polipapers.upv.es/index.php/EGA/article/view/1335, 2011 (in Spanish) (accessed 8 January 2017). DOI: 10.4995/ega.2011.1335.

[10] Johnston, P. (ed.), The Function of the Oblique: The Architecture of Claude Parent and Paul Virilio 1963-1969, AA Publications: London, 2004. 